\title{
STRUCTURES IN DEPOSITS FROM BEACH RECOVERY, AFTER ERO- SION BY SWELL WAVES AROUND THE SOUTHWESTERN COAST OF ARUBA (NETHERLANDS ANTILLES)
}

\author{
J.H.J. TERWINDT ${ }^{1}$, C.H. HULSBERGEN ${ }^{2}$ and L.H.M. KOHSIEK ${ }^{1}$ * \\ ${ }^{1}$ Department of Physical Geography, State University of Utrecht, P.O. Box 80.115, \\ 3508 TC Utrecht (The Netherlands) \\ ${ }^{2}$ Delft Hydraulics Laboratory, P.O. Box 152,8300 AD Emmeloord (The Netherlands)
}

(Received February 21, 1983; revised and accepted July 14, 1983)

\section{ABSTRACT}

Terwindt, J.H.J., Hulsbergen, C.H. and Kohsiek, L.H.M., 1984. Structures in deposits from beach recovery, after erosion by swell waves around the southwestern coast of Aruba (Netherlands Antilles). In: B. Greenwood and R.A. Davis, Jr. (Editors), Hydrodynamics and Sedimentation in Wave-Dominated Coastal Environments. Mar. Geol., 60: $283-311$.

Hurricane- or storm-generated swell waves may cause erosion and deposition along coasts which are situated thousands of kilometers outside the generating wind field. Marked beach erosion, caused by such swell waves, was observed along the micro-tidal west coast of Aruba. During the process of erosion a swash bar was formed, which moved up-beach during the waxing part of the swell event. The swash bar welded to the beach during the waning part of the event. Rapid sedimentation occurred on the upper beach. Finally, recovery of the beach was observed. The formation of a swash bar was attributed to an erosive, dissipative interval of a normally accretionary reflective beach. The sedimentary structures, although generally in line with observations on other beaches, show several peculiar characteristics: (1) the great thickness of the laminae in these calcareous sands; (2) the succession of low-angle sigmoidal and tangential sets in the swash bar; (3) the relatively steep erosional lower set boundaries and the wedge-shaped lamination in the successive stages of beach recovery; and (4) the several types of deformation structures.

\section{INTRODUCTION}

The destructive effect of swell waves generated by hurricanes or severe storms which pass or hit coastal zones has been long recognized in different parts of the world (Howard, 1939; McKee, 1959; Hayes, 1967; Stoddart, 1971; Hopley, 1974; Kumar and Sanders, 1976). It has generally been observed that in most cases the recovery of the beaches takes place rather rapidly after the swell has ceased (King and Williams, 1949; Reineck, 1963; Hayes, 1967; Hayes and Boothroyd, 1969; Davis et al., 1972; Owens and Frobel,

*Present address: Rijkswaterstaat, Delta Service, Van Alkemadelaan 400, 2597 AT The Hague, The Netherlands. 
1977). However, the effects of hurricanes and storms are not restricted to areas in the vicinity of the track of the eye. The generated swell waves may influence coastal processes in areas, thousands of kilometers outside of the wind field.

Along the west coast of the island of Aruba (Netherlands Antilles), the existence of such swell waves, having travelled a considerable distance, was demonstrated by Wilson $(1968,1969)$ and Wilson et al. (1973). The low, but long waves, reaching shallow water produce high breakers, which cause havoc and damage to the recreational resort areas (Kohsiek et al., in prep.).

The sequence of events in the surf zone during erosion and initial recovery of the beach is difficult to establish because profiling and diving is almost impossible during heavy surf. Another way to analyse these events is to study the sedimentary succession. Three large, $2 \mathrm{~m}$ deep trenches were excavated across the entire beach after an erosional event. This paper describes the observed characteristics of the exposed sediments.

\section{GENERAL SETTING OF THE AREA OF INVESTIGATION}

Aruba is situated in the Caribbean Sea in the zone swept by the east trade winds (Fig.1). The mean wind velocity is about $7.7 \mathrm{~m} \mathrm{~s}^{-1}$. There are minor seasonal variations in wind direction and speed. The diurnal tides are low around Aruba: the spring tidal range is $0.43 \mathrm{~m}$ and the neap range is $0.13 \mathrm{~m}$.

The wave climate is almost exclusively dominated by the trade winds. In the Caribbean Sea the wind waves are heading to the west for $67 \%$ of the time, for $18 \%$ to the southwest and for $11 \%$ to the northwest. The average wave height is about $1.5 \mathrm{~m}$ and the average period is $7 \mathrm{~s}$.

The calcareous sandy beaches are situated at the leeward side of the island between Malmok and Oranjestad (Fig.2) and are unprotected by barrier reefs. The latter are present to the southeast of Oranjestad.

The westernmost part of the island is called Manshebu and the present study is focused on Pelican Beach between Manshebu and Oranjestad and on Eagle beach between Manshebu and Pos Chikitu (a bluff of an old lower terrace barrier reef deposit).

\section{HURRICANES AND TROPICAL STORMS AFFECTING THE AREA}

The effect of tropical storms $(8-11 \mathrm{~B})$ or hurricanes $(>11 \mathrm{~B})$ on the Aruban beaches differs whether the track is within or without the Caribbean Island Arch.

Within the Arch the storms are generated in the east and track toward the west. As a result, important variations in wind velocity and wind direction may occur and this affects the direction of the swell waves. Around Aruba the swell starts heading to a westerly direction merging in time toward the south and finally toward the southeast. An example is presented in Fig. 3, illustrating the track of the Hurricane David (Aug.-Sept. 1979) 


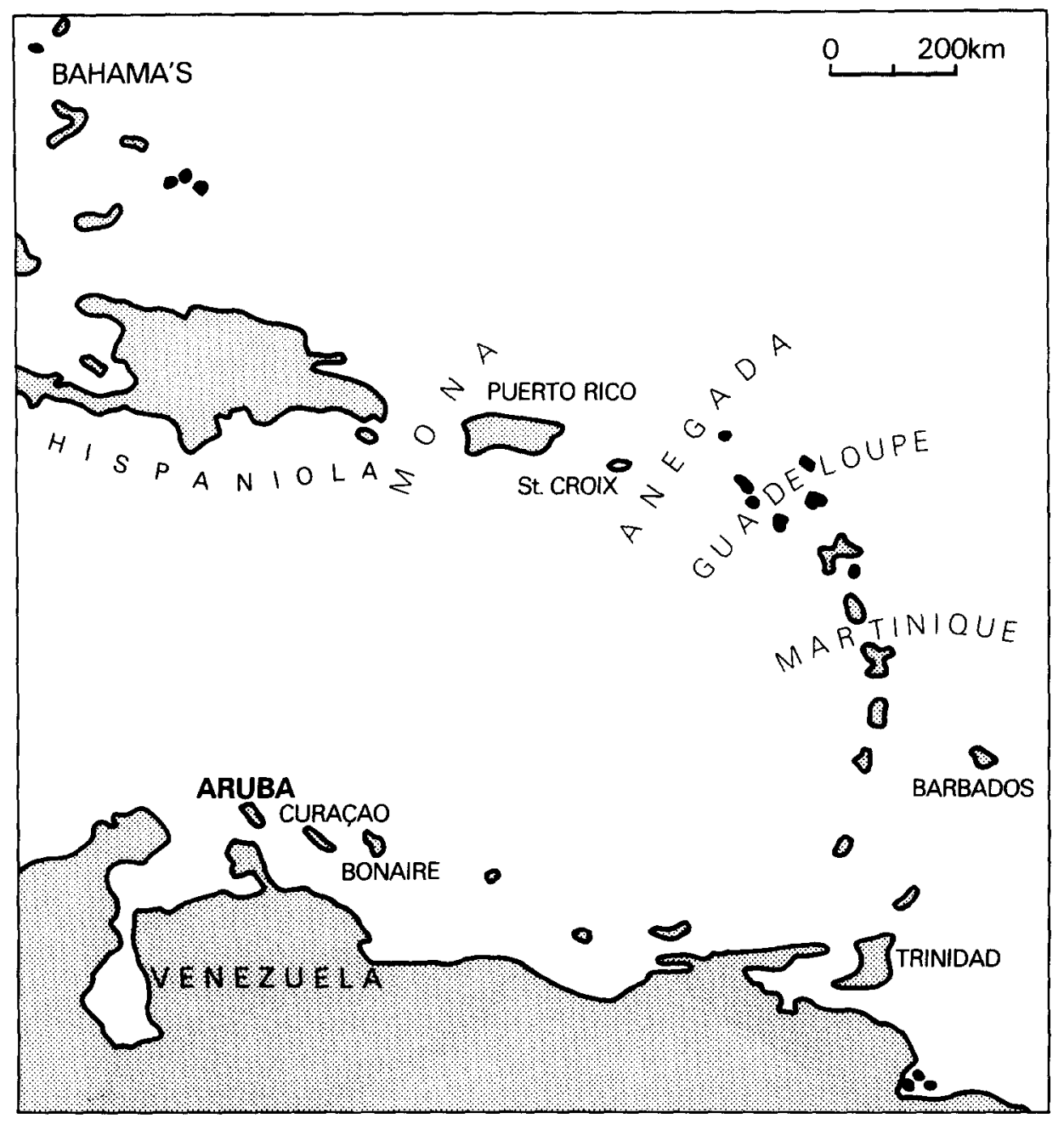

Fig.1. Location map of the eastern part of the Caribbean.

and the successive wave fields. Since 1970 , a total of 19 tropical storms or cyclones has passed the $70^{\circ} \mathrm{W}$ meridian in the vicinity of Aruba.

Aruba may also be reached by waves generated by storms or hurricanes tracking over the Atlantic, north of the Caribbean Island Arch. These storms move from east to west, and if powerful enough, may generate wind waves of sufficient height to become swell waves. Only swell waves travelling in the direction of the corridors, the Mona and Anegada Passage, and sometimes even the Guadeloupe and Martinique Passage, can enter the Caribbean Sea. This means that in the Caribbean, the travelling direction is more uniform, while, due to the greater distance, the wave height is smaller and the period longer in comparison with the Inner Arch swell waves under similar boundary conditions. In Table I some recent data are gathered for events of 


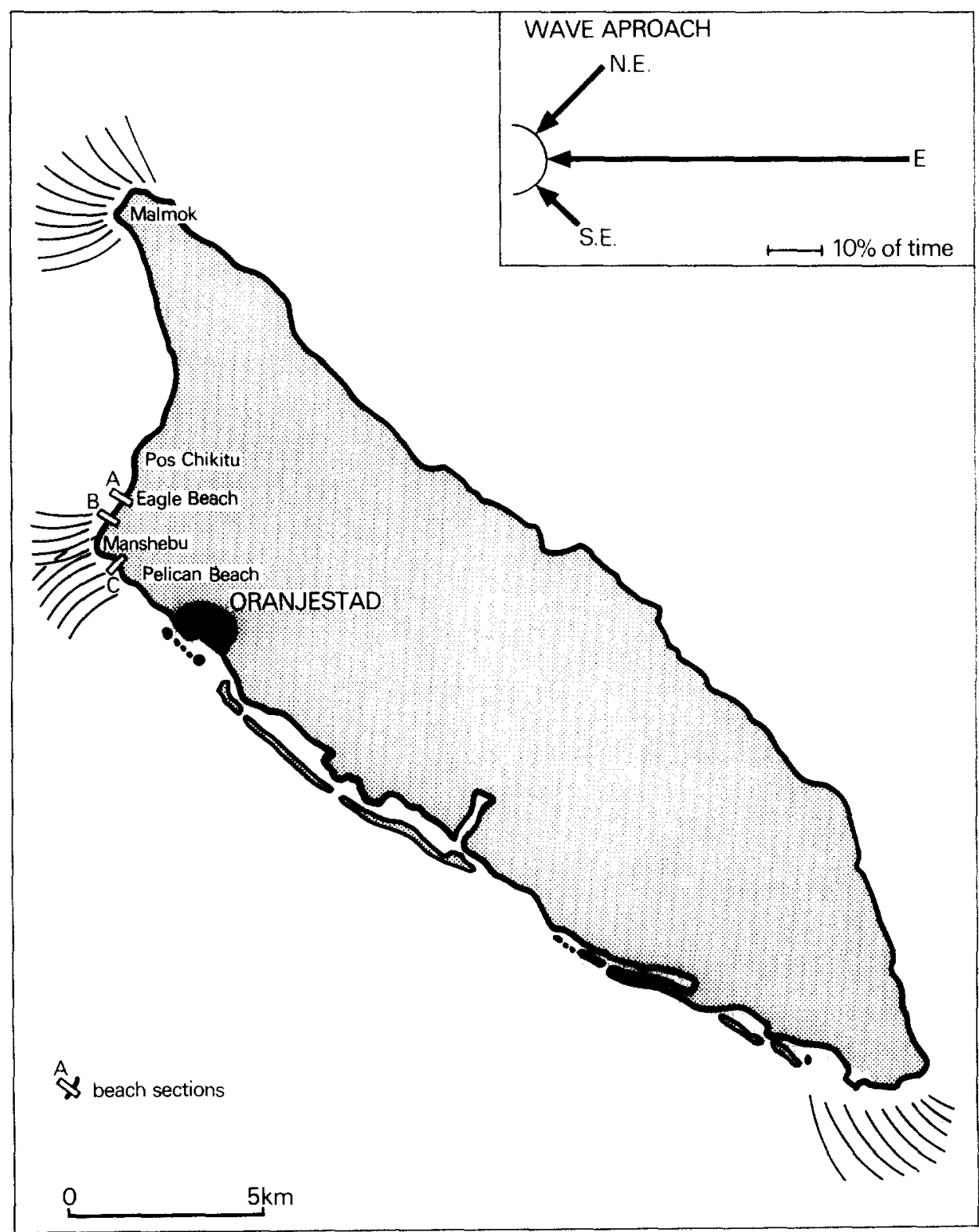

Fig. 2. Island of Aruba. Sandy beaches are situated between Malmok and Oranjestad. Dominant wave approach is from the east; wave refraction takes place around the north and south capes of the island; the meeting area of refracted waves is near Manshebu.

severe erosion along the west coast of Aruba and the inferred tracks of tropical cyclones on the Atlantic.

In conclusion, Aruba may be reached by different types of swell waves either being multi-directional with variable travelling distances or uni-directional with long travelling distances. 


\section{TABLE I}

Recent data on erosional events along the west coast of Aruba and the hindcast causes and swell wave tracks

\begin{tabular}{|c|c|c|}
\hline $\begin{array}{l}\text { Date of severe erosion } \\
\text { on Aruban coast }\end{array}$ & $\begin{array}{l}\text { Meteorological cause; } \\
\mathrm{L}=\text { low } \mathrm{H}=\text { high }\end{array}$ & $\begin{array}{l}\text { Inferred passage of the } \\
\text { Caribbean Island Arch }\end{array}$ \\
\hline Nov. 24,1977 & L, Cuba to Puerto Rico & Anagada \\
\hline Dec. 1,1977 & $\mathrm{H}$, Atlantic $50^{\circ} \mathrm{W}, 35^{\circ} \mathrm{N}$ & Guadeloupe or Martinique \\
\hline Feb. 16, 1978 & $\mathrm{~L}$, north of Cuba & Mona \\
\hline Aug. 26, 1978 & L, near Cuba & Mona \\
\hline Nov. 18,1978 & L, northeast of Puerto Rico & Mona \\
\hline Feb. 20,1979 & L, east of Florida & Anagada or Guadeloupe \\
\hline May 21, 1979 & $\mathrm{~L}$, north of Hispaniola & Mona \\
\hline
\end{tabular}

THE EFFECT OF WIND AND SWELL WAVES ON THE SAND MOVEMENT

Wind and swell waves approaching the east coast of Aruba are refracted around the north and south capes of the island (Fig.2). These refracted waves meet each other at the west point of the island near Manshebu, generating a complicated cross pattern (Fig.4). The location of this meeting area and the dominancy of one pattern over the other depends on the direction of the incoming wave trains.

Under normal wind wave conditions the meeting area of the refracted waves is situated just west of Manshebu. There is a net longshore drift along Pelican as well as Eagle Beach towards Manshebu (Kohsiek et al., in prep.) resulting in an accumulation of sediment at the west point (Fig.5).

A different refraction pattern occurs during the presence of swell waves which originate from outside the Caribbean Arch and come from a more northerly direction. The southward travelling waves dominate along Eagle and Pelican Beach, resulting in a southward littoral drift (Fig.5).

If the swell waves are derived from a storm within the Caribbean Arch, the refracted waves approach the west point dominantly from the northwest, gradually shifting toward the west. Thus, at first, there is an increasing littoral drift and erosion along Eagle Beach and, at Manshebu, a decreasing drift and even sedimentation along Pelican Beach. Swell, approaching from the west causes erosion at Manshebu but ultimate accretion along Eagle and Pelican Beach (Fig.5).

It appears that the littoral drift during a swell event is partly opposite to that of the normal wind wave conditions. As an example Fig. 10 compares the net sediment movement during normal conditions with that during the passage of the hurricane David (Aug.-Sept. 1979). The sediment discharge estimates are based on beach profiling and measurements of wave characteristics, angle of incidence and littoral currents. The breaking swell waves created high sediment transport during a short time as compared with the wind wave transport. Furthermore, these high breakers caused a rapid erosion of the foreshore and backshore. The eroded sediment is partly transported offshore below the breaker zone, but a larger part is transferred to 

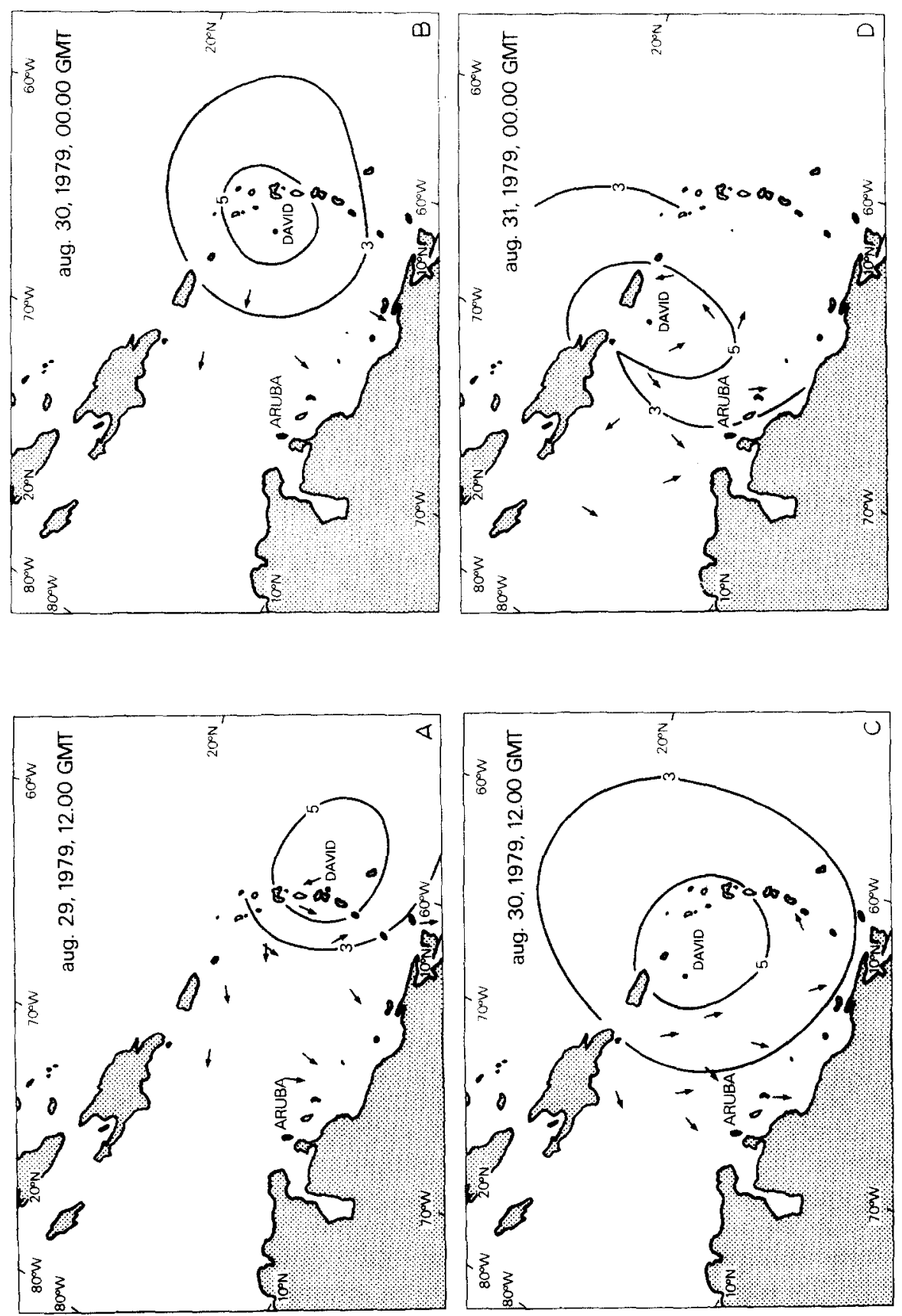


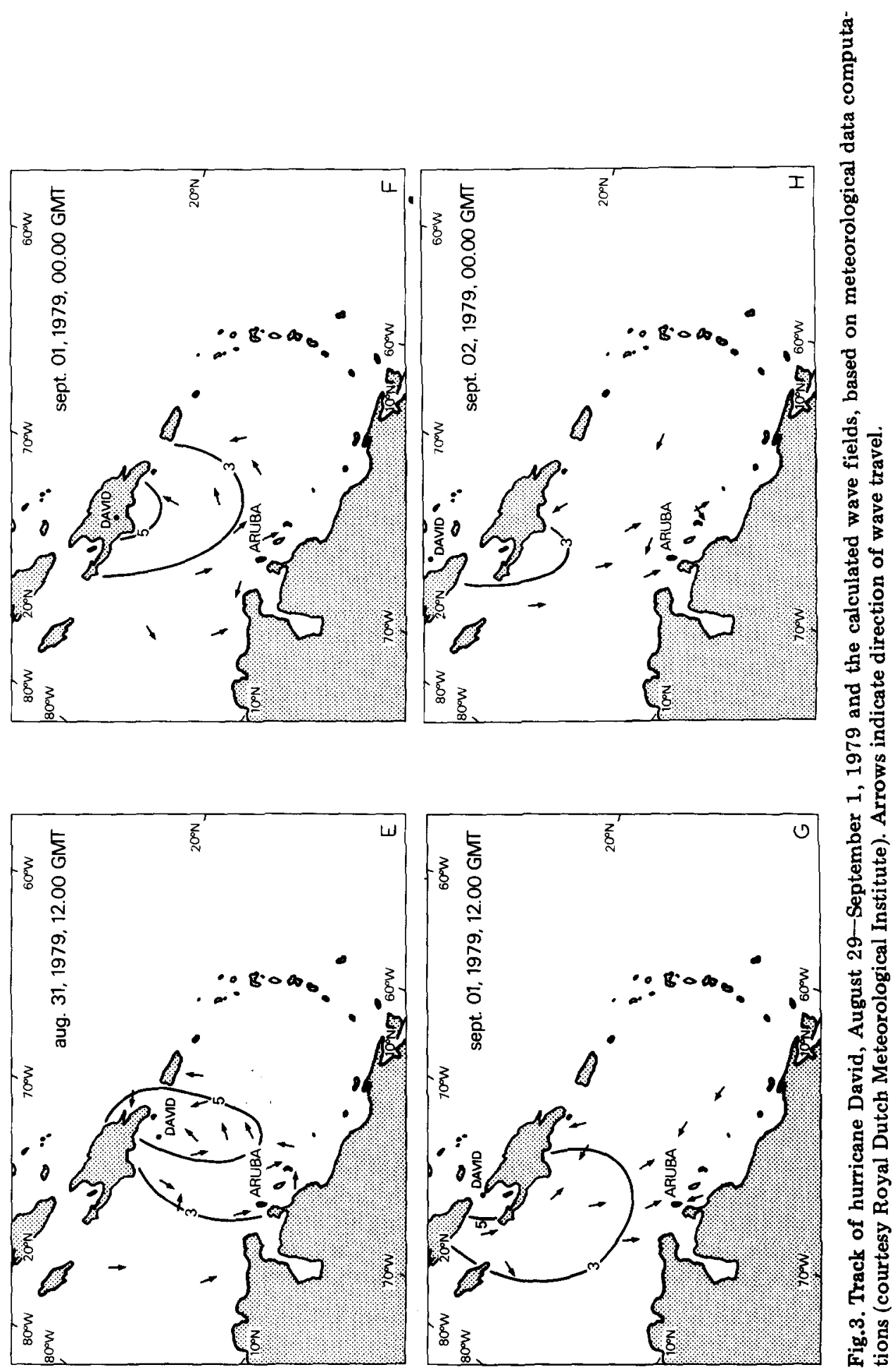


adjacent stretches of the coast, as is evidenced by the changes in the beach profiles. When the swell ceases the sediments gradually return by the action of the smaller wind waves.

\section{DESCRIPTION OF SECTIONS}

The main purpose of this study was the ultimate fate of the beach sediments and the way in which erosion changes into accretion and the restoration of the beach during recovery.

Three sections, $2 \mathrm{~m}$ deep, were excavated crossing the entire beach. Two were located on Eagle Beach and one on Pelican Beach. The sections showed almost similar features and therefore only one (A on Fig.2) from Eagle Beach will be treated here in detail.

All sections comprise the deposits of coastal recovery after a heavy erosion by swell waves which occurred in the beginning of April 1979. The profile of the ultimate erosion could be established by a deposit of rocks, broken asphalt and coral rubble which was dumped by the local authorities in order to stop or delay the retreat of the beach. It appeared that soon after the dumping of the rocks, etc., the beach erosion stopped, the wave climate calmed down and the beach recovery started. The sections were made on 9-10 May 1979, about 4 weeks after the erosion. During this time the beach recovery was $20-25 \mathrm{~m}$; a mean of about $0.8 \mathrm{~m}$ per day.

Eleven sedimentary units can be distinguished in the section under consideration (Fig. 6). The boundaries between the units are erosional surfaces. The units are numbered according to their inferred order in the succession of the recovery. The section shows a landward dipping part (unit 1a-1e), an almost horizontal part (unit 2, 4-6) lying on top and landward of unit $1 \mathrm{c}$ and several seaward dipping units $(3,5-11)$. A similar distinction could be made in the other sections.

In the sections from Eagle Beach and Pelican Beach, dumped rock and pieces of asphalt originating from the erosion prevention measures are found on top of the landward dipping unit and are incorporated in the first seaward dipping unit, comparable to unit 3 (Fig. 6). The horizontal and seaward dipping units lie above this rubble. This indicates that unit 1 was deposited before the dumping of the fill. As it was impossible to perform beach profiling during the period of heavy swell we cannot be absolutely sure that the landward dipping unit was deposited during the swell period and that it is not a relict. However, we think that unit 1 fits very well in the deduced succession of events, and the accompanying deposits.

Furthermore, a similar unit is present in all sections and in a similar setting (approximate distance from the shore, position and height in the profile, the character of adjacent units). Thus, although not certain, we consider unit 1 to belong to the sequence of swell erosion and recovery of the beach. 


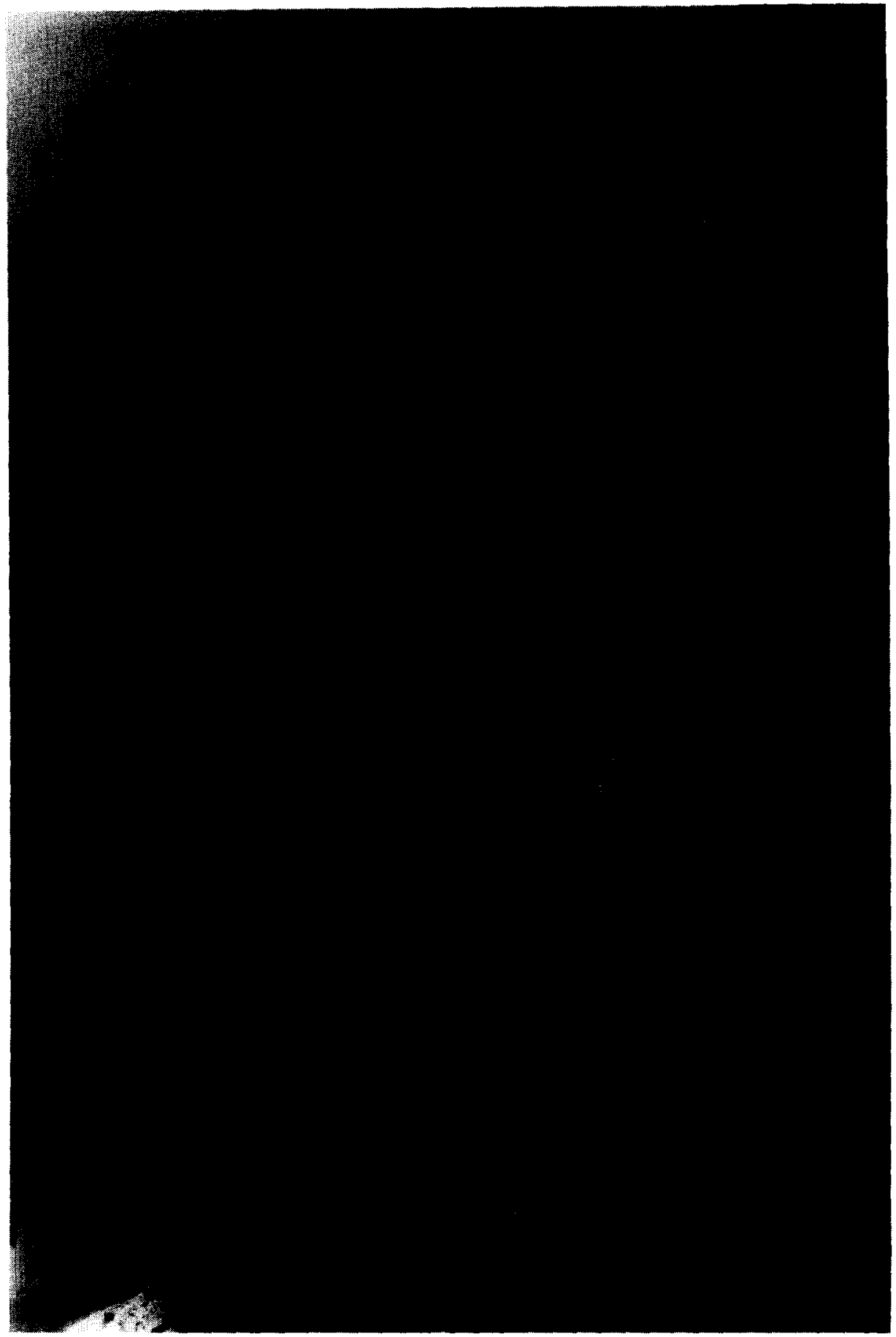

Fig.4. Aerial photograph of the cross-pattern of refracted waves near Manshebu. 


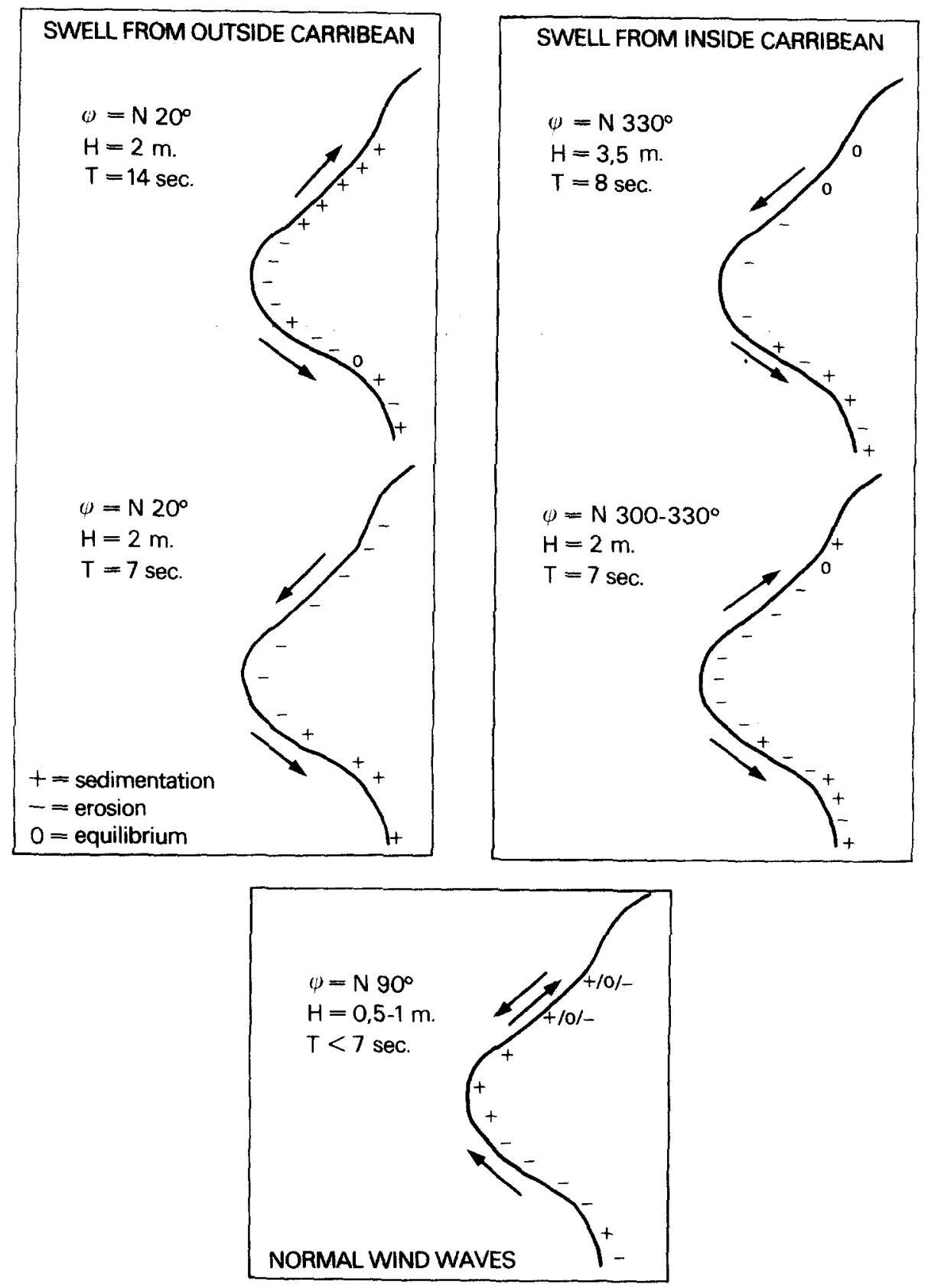

Fig.5. Erosion and sedimentation on the west coast of Aruba (Manshebu) in relation to swell and wind-wave conditions. 

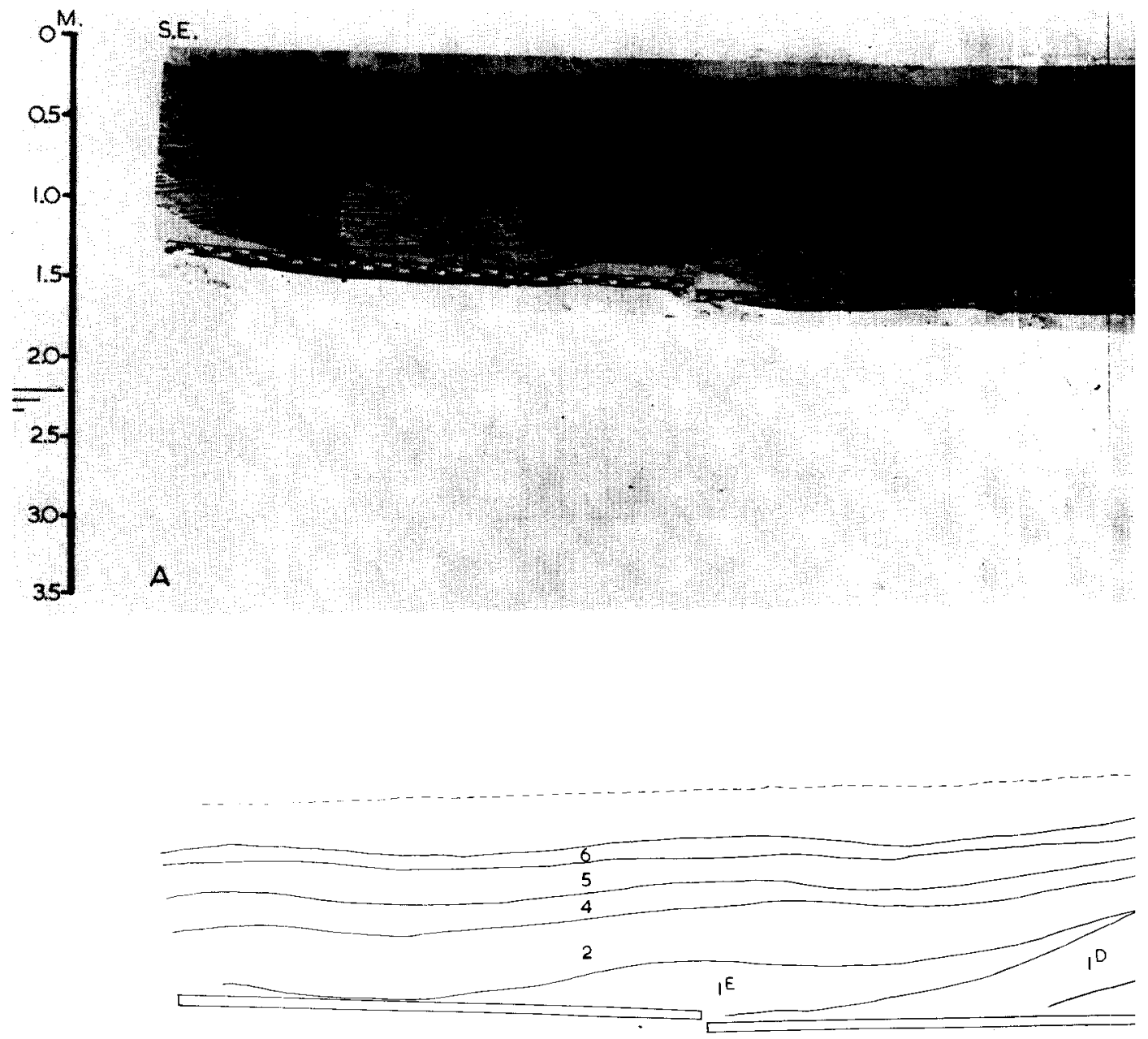

B

Fig, 6. Section showing sedimentary structures across Eagle Beach. 


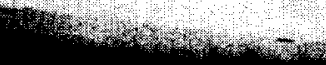
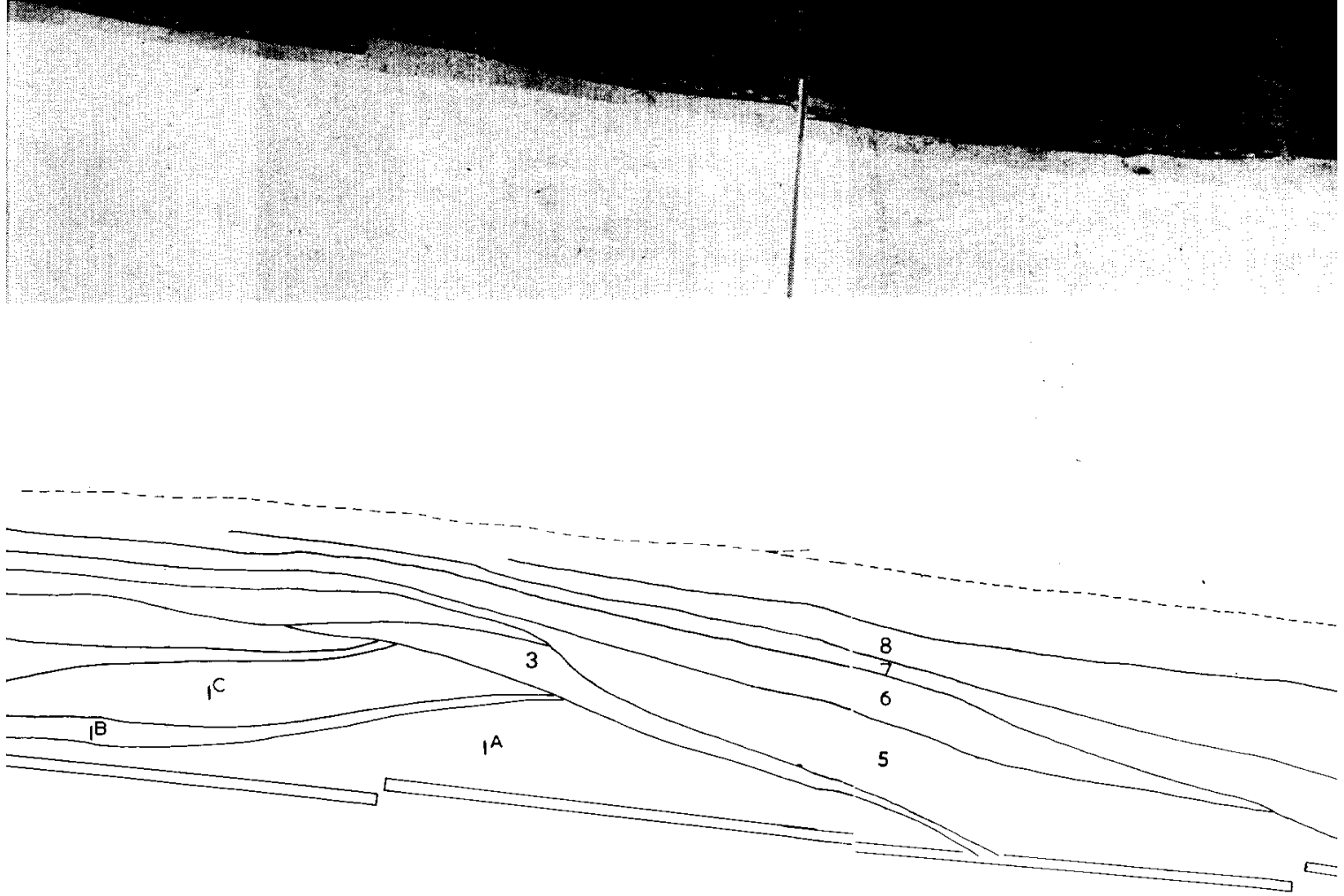

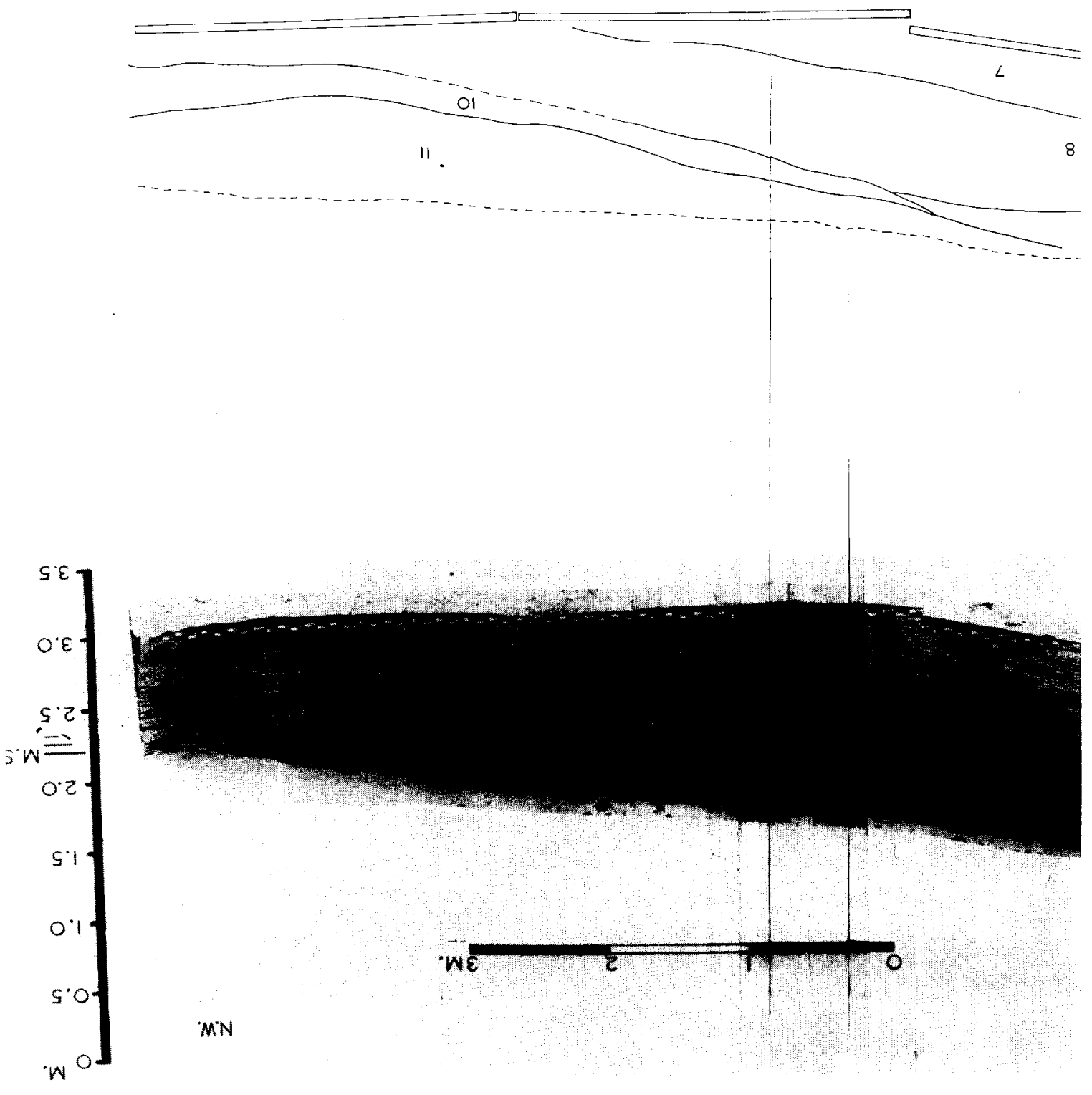
pp. $296-298$

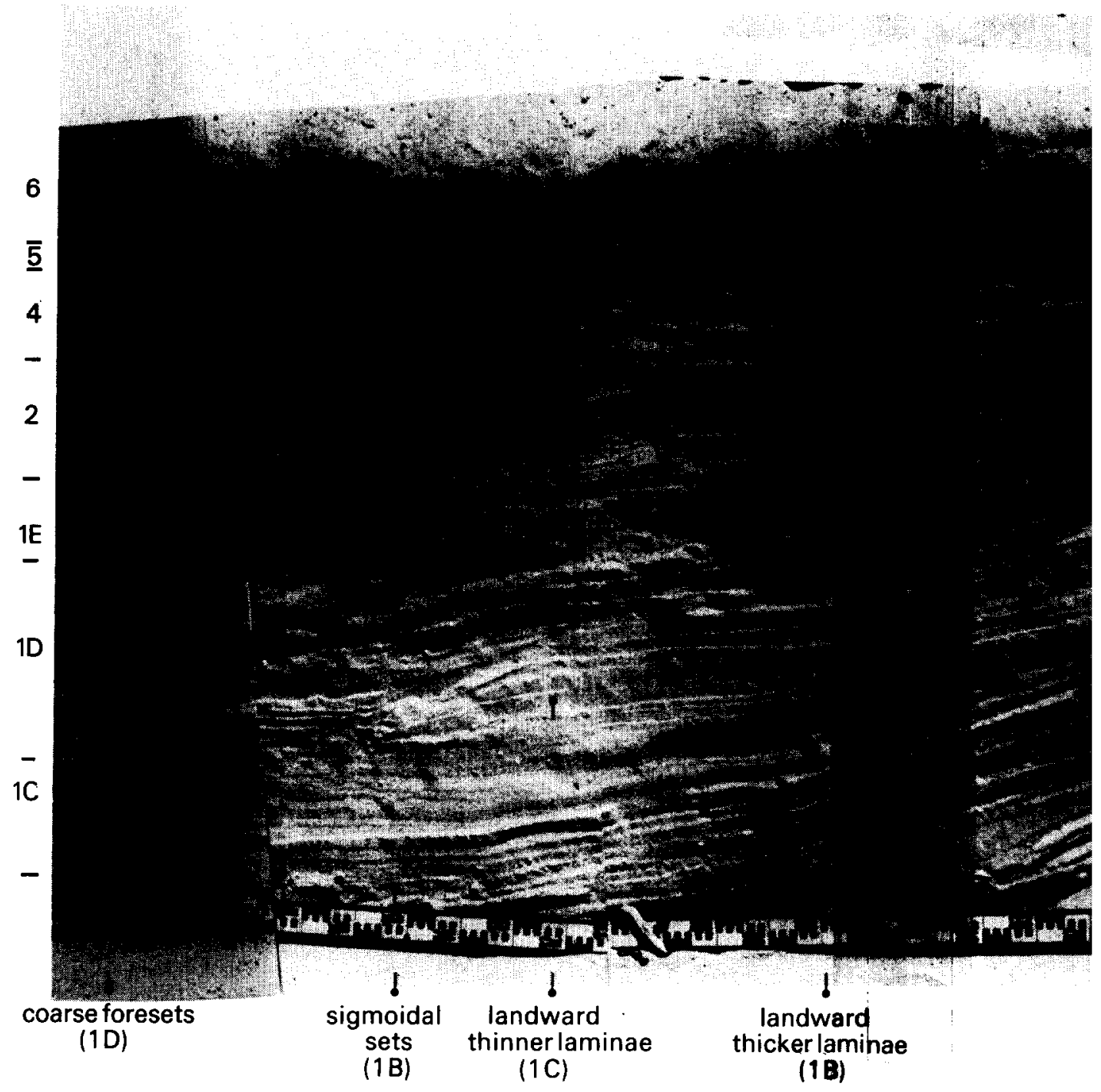

Fig. 7. Detail of section, showing the landward dipping unit 1. 


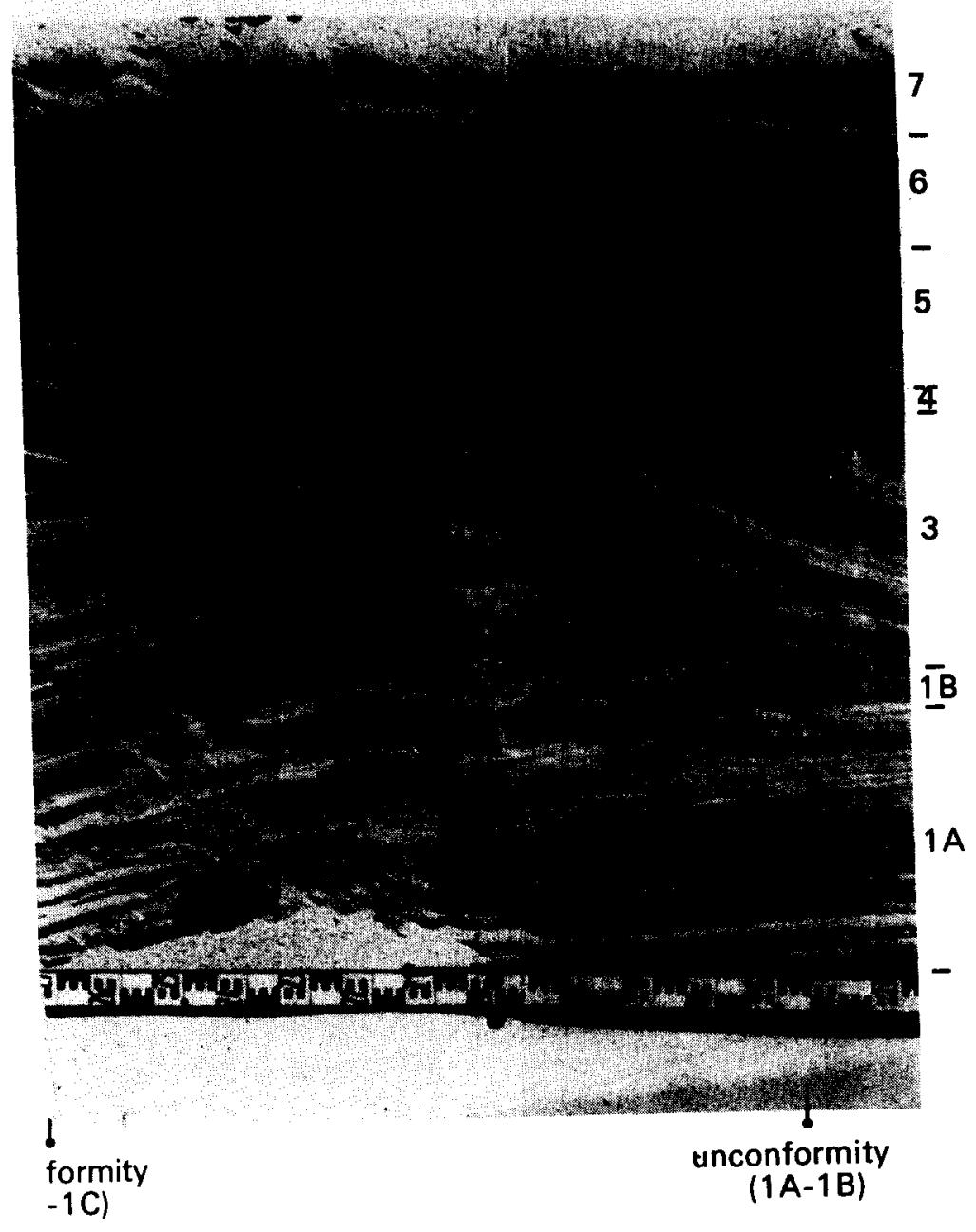





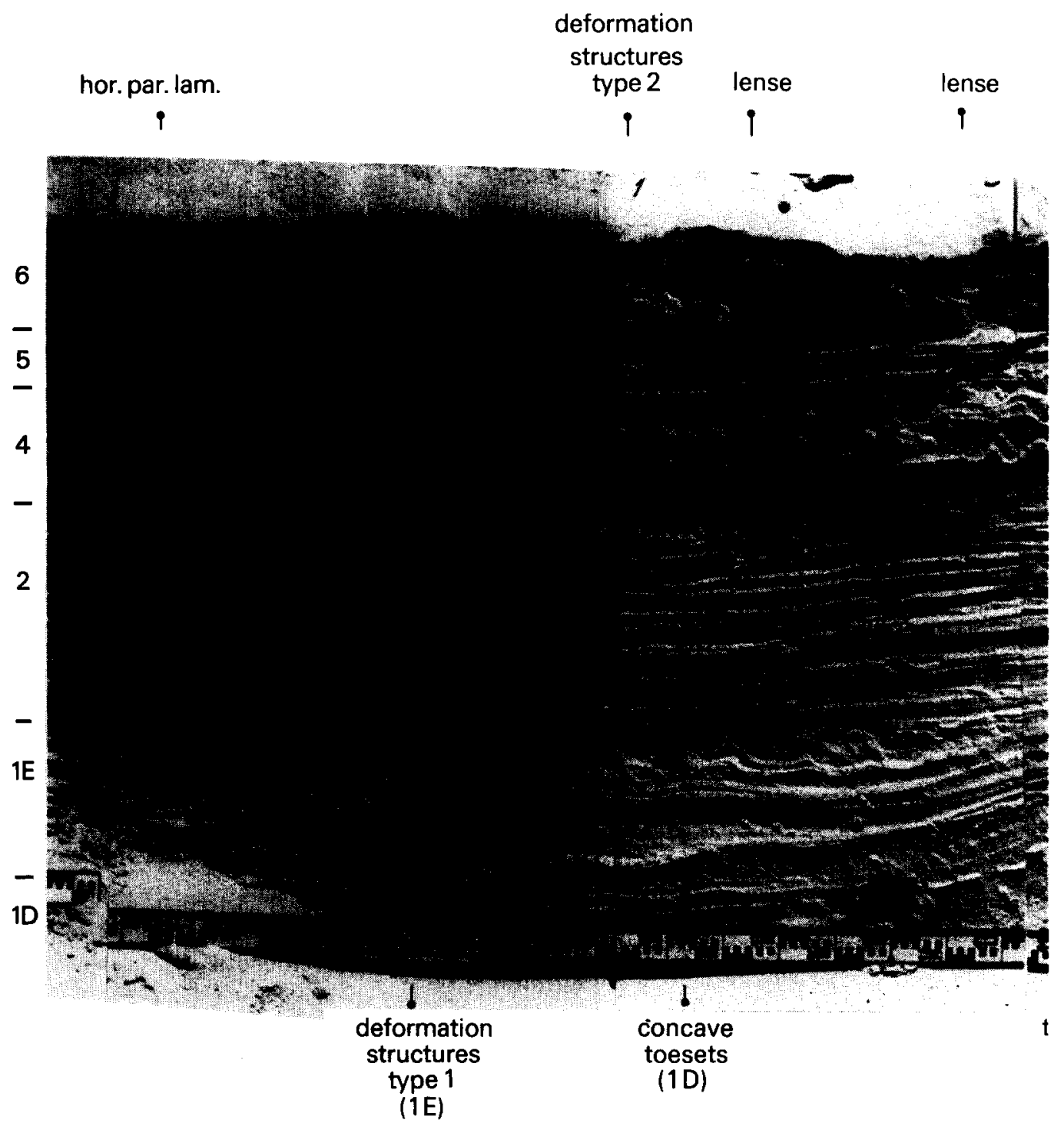

Fig. 8. Detail of section, showing units 1,2 , and $4-6$. 
pp. $299-300$

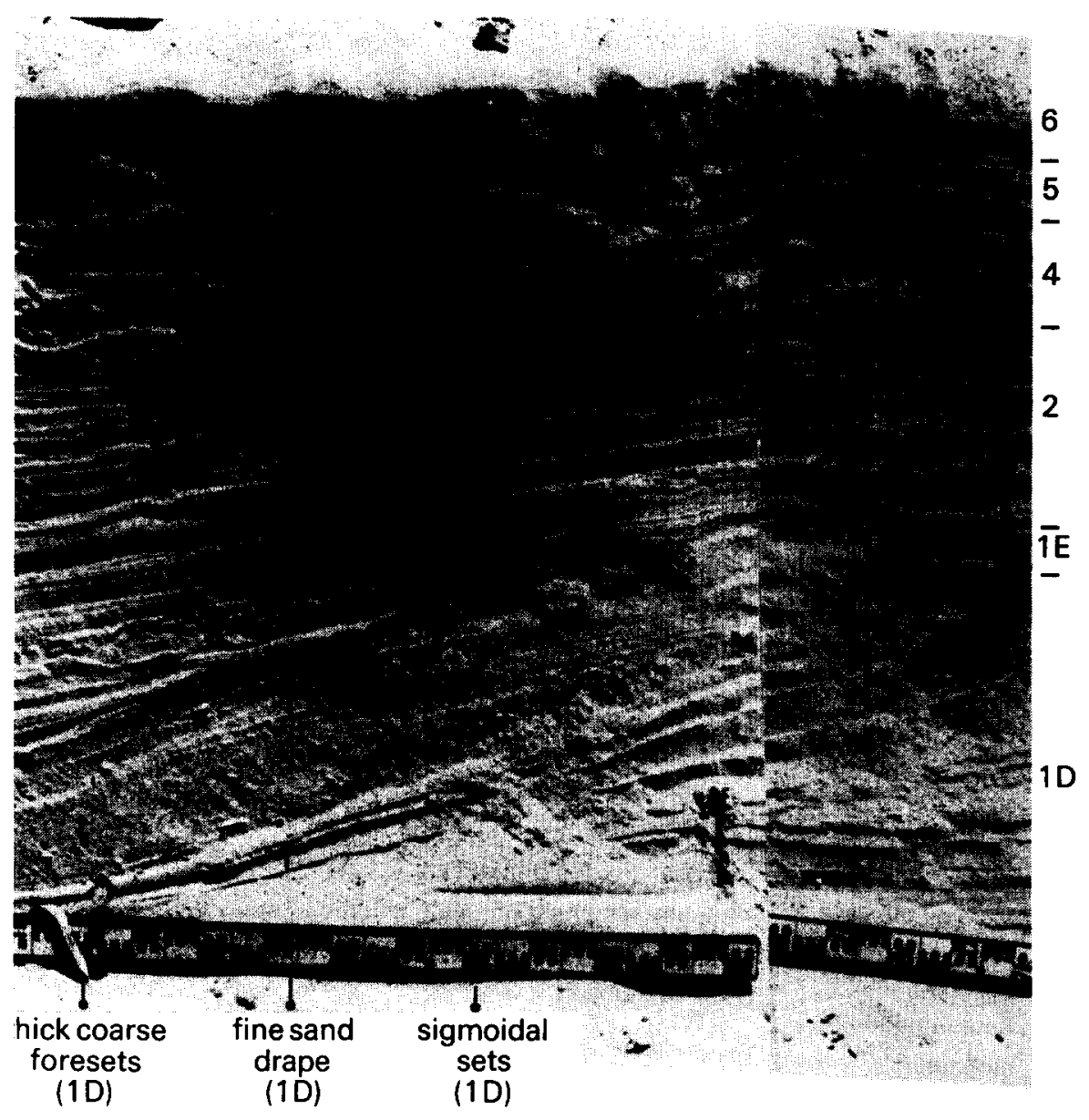




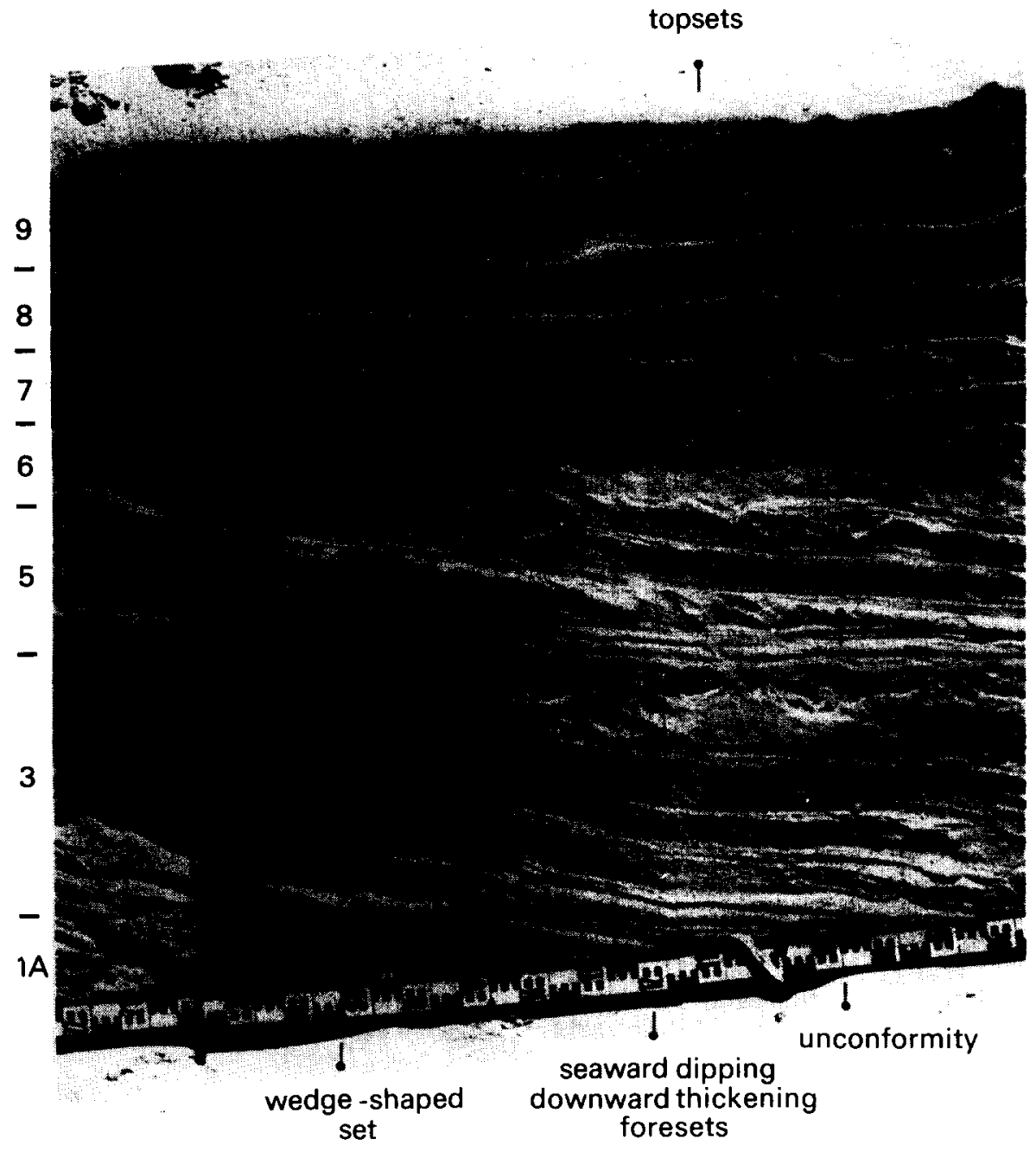

Fig. 9. Detail of section, showing units $1 \mathrm{a}, 3,5$, and 6-9. 


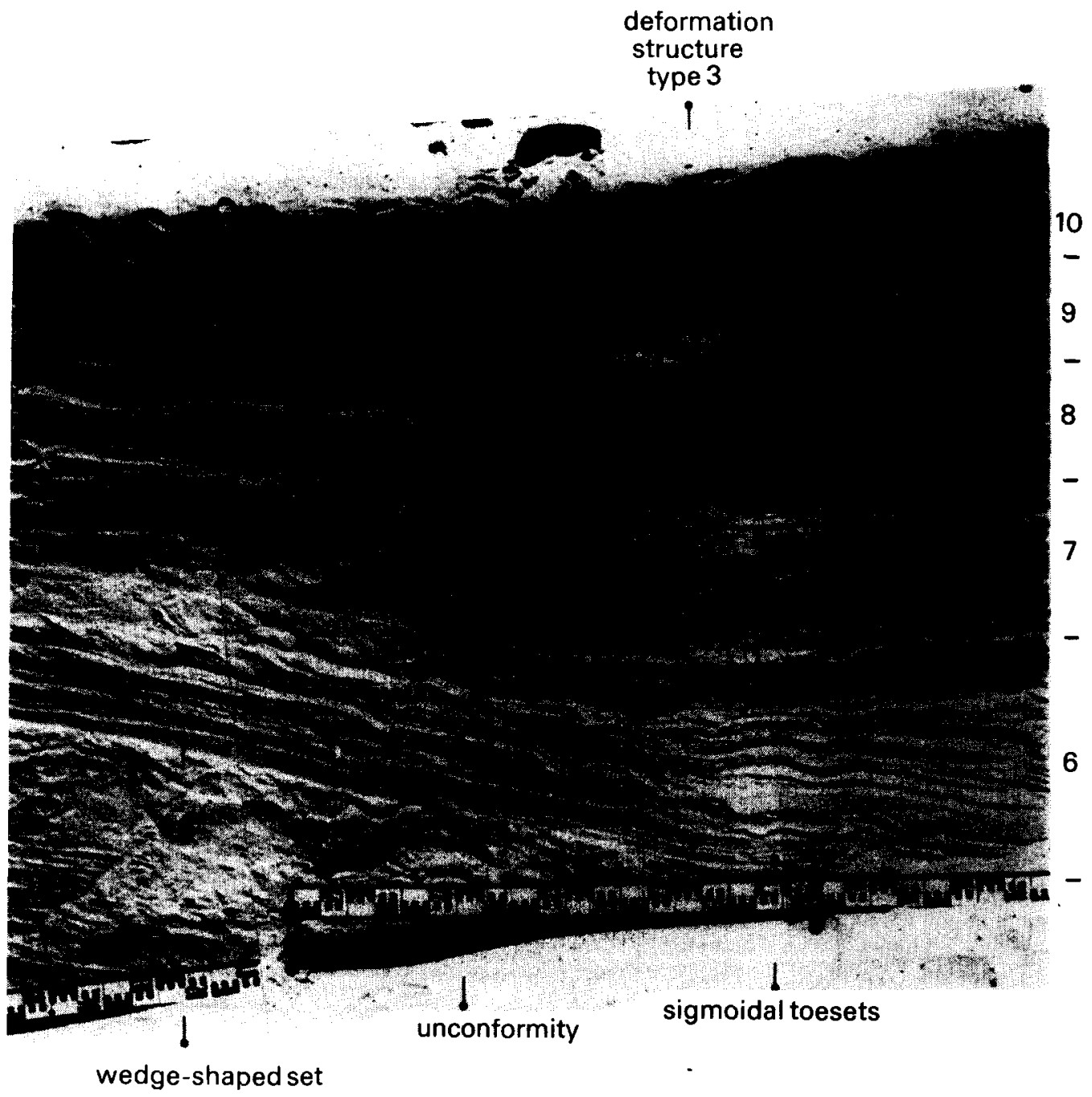




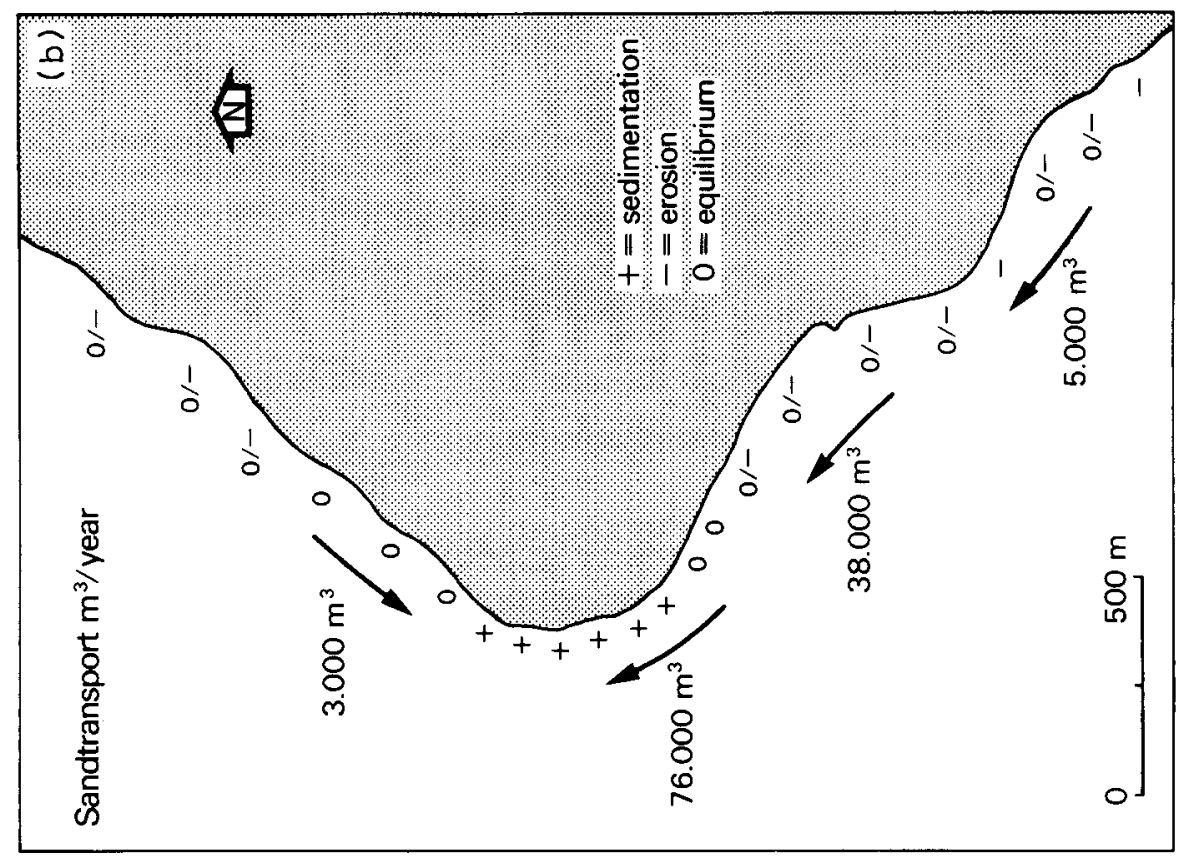

号

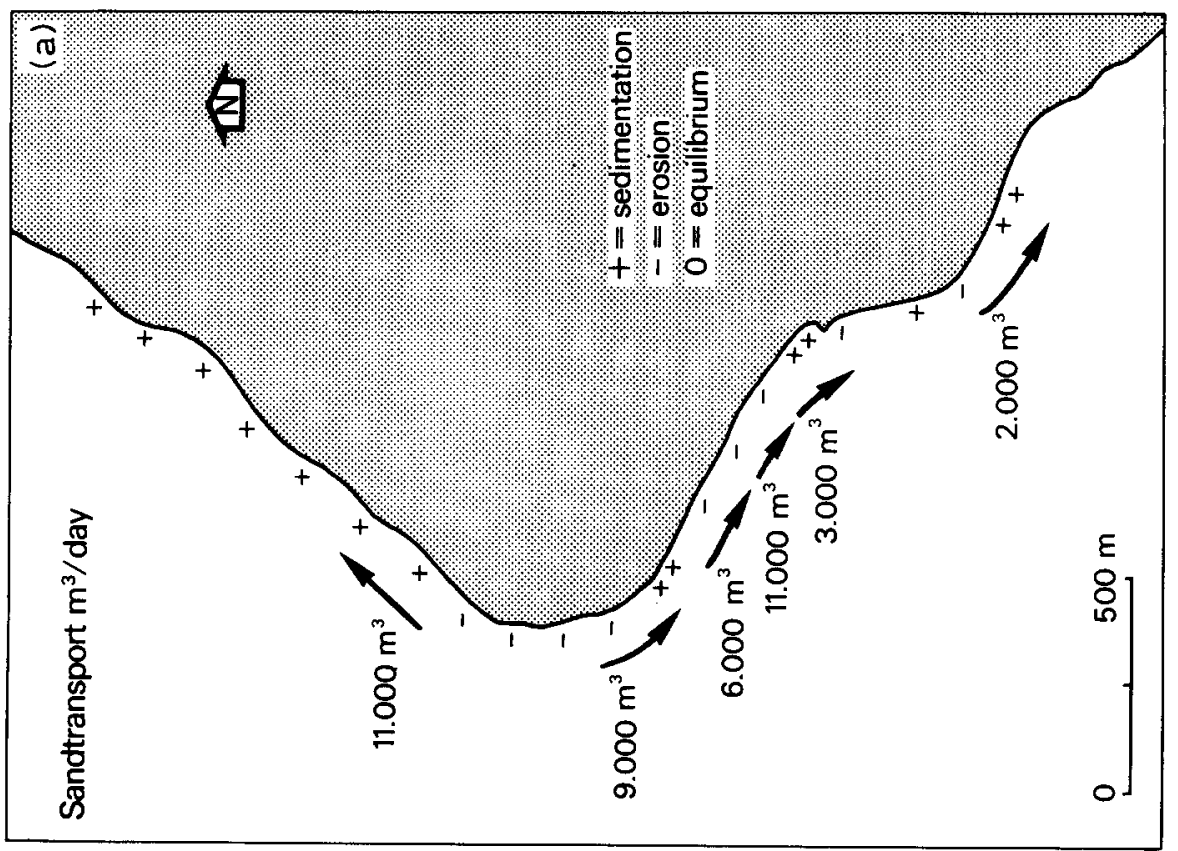

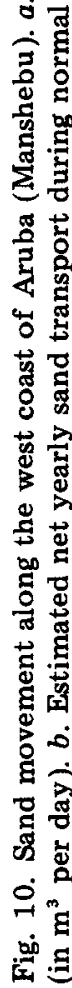




\section{Unit 1}

This unit is made up of low to moderate dipping landward, cross-strata (Figs. 7 and 8). The unit is subdivided into five subunits (Fig. 6). The boundaries are unconformities, either erosion surfaces or sudden and marked changes in textures and/or structural properties (foreset angles, nature of toesets, specific changes in thickness of the laminae).

Unit $1 \mathrm{a}$ is coarse at the base $\left(d_{50}=1.0-1.5 \mathrm{~mm}\right)$, including small coral rubble and fines upward to medium $/$ coarse sand $\left(d_{50}=0.4-0.8 \mathrm{~mm}\right)$. The basal horizontal lamination merges upward and landward into landward dipping $\left(15-20^{\circ}\right)$ foresets and toesets.

Unit $1 \mathrm{~b}$ shows a much finer sediment $(0.4-0.6 \mathrm{~mm})$ and the structures consist of very thinly laminated almost horizontal lamination, in landward direction gradually merging into low-angle $\left(10^{\circ}\right)$ foresets and sigmoidal toesets. The laminae become progressively thicker going landward.

Unit 1c differs from $1 \mathrm{~b}$ in that the foresets are better developed, are somewhat steeper $\left(15^{\circ}\right)$, have thicker laminae, but the toesets are concave and the laminae become progressively thinner.

Unit $1 \mathrm{~d}$ is a continuation of unit $1 \mathrm{c}$, but there are differences; the subhorizontal topsets are very thin and there is almost no vertical accretion. There are thick, coarse-grained $(0.8-1.2 \mathrm{~mm})$ foreset laminae, which become thinner toward the concave toesets. Two of such coarse-grained foreset beds can be distinguished, separated by a thin intercalation of finer material consisting of concave foresets and sigmoidal fore- toesets.

Unit $1 \mathrm{e}$ shows concave topsets merging into increasingly thicker foresets and sigmoidal toesets, in rather coarse material $\left(d_{50}=1.2-1.5 \mathrm{~mm}\right)$.

\section{Unit 2}

This unit consists primarily of thin, horizontal or slightly landward dipping parallel lamination in medium-sand $\left(d_{50}=0.3-0.5 \mathrm{~mm} ;\right.$ Fig. 8). Most laminae can be traced over $2-5 \mathrm{~m}$ and landward they become thicker. Some very flat lenses may be observed.

\section{Units $3-11$}

Each unit is bounded at the base by an erosional surface, truncating the underlying strata. The units show almost similar characteristics throughout. Going from the beach toward the sea, the units consist of almost horizontal, parallel lamination which merge into seaward-dipping downward-thickening foresets and sigmoidal, almost horizontal, parallel-laminated toe and bottomsets (Fig. 9).

The increasing thickness of the laminae results in a wedge-shaped set with gradually flattening foreset angles. This would finally lead to very low 
dipping strata. Occasionally, however, there were erosional conditions which resulted in erosion surfaces having a steeper slope than the underlying strata. In most cases coarser sediment gradually fines upward from these erosion surfaces.

The almost horizontal nature of slightly landward-dipping topsets is nearly concordant with unit 2 . However, the material is much coarser and the laminae become progressively thicker in landward direction.

The deposition of units 3-11 resulted in an overall aggradation.

\section{INTERPRETATION}

Initially the interpretation of the sedimentary units does not seem to be very problematic.

Many authors have provided evidence that the landward-dipping stratification like that of unit 1 may be attributed to a shoreward migrating bar (Reineck, 1963; Panin, 1967; Psuty, 1967; Hayes and Boothroyd, 1969; Clifton et al., 1971; Davis et al., 1972; Davis and Fox, 1972; Wunderlich, 1972; Davidson-Arnott and Greenwood, 1976; Fraser and Hester, 1977; Owens and Frobel, 1977; Van den Berg, 1977; Hine, 1979; Hunter et al., 1979; Greenwood and Davidson-Arnott, 1979).

Unit 2 may be interpreted as an infilling of a depression landward of the bar. This infilling finally results in a welding of the bar to the beach, analogous to the description by Sonu and Van Beek (1971), Davis et al. (1972), Wunderlich (1972), Sonu (1973), Owens and Frobel (1977), Van den Berg (1977), Hine (1979), Short (1979) and Wright et al. (1979).

Units 3-11 may be referred to as the seaward outbuilding (recovery) of the beach showing similar deposits as described by Thompson (1937), Panin (1967), Clifton et al. (1971), Davis et al. (1972), Van den Berg (1977), Hine (1979) and Hunter et al. (1979).

Although these general interpretations are supported by previous observations of many investigators, several peculiar points may be recognized when looking in greater detail.

First, a decision has to be made as to whether unit 1 belongs to the swell event or is a relict of a former beach deposit. During the heavy swell the beach was strongly eroded and the strand line shifted landward. The bottom sets of units 3-7 were not exposed and were below the base of the section. The same holds for unit 2. This seems to indicate that the lowermost beach profile, which developed during the April swell event lies below the present section. Unfortunately this lowermost profile could not be excavated because it is situated below the ground water table. Unit 1 in this conception lies above the lowermost erosion profile. Furthermore, if unit 1 was a relict bar then an overall truncation plane should be present on top of the unit. There are truncations on the upper side, but not on the landward side. Here unit 1 gradually merges into unit 2 , which may indicate a genetic relationship. Thus, we think that it is justified to incorporate unit 1 in the features connected with the swell event of April 1979. 
Under normal conditions of refracted wind waves, the Aruban beaches have an almost straight, uniform beach profile, dipping at about $6-8^{\circ}$ with no bars and a small $0.1 \mathrm{~m}$ high step at the seaward side of the swash zone (Fig.11). The step is composed of very coarse sand and coral rubble. Below the step there is a linear, low-gradient nearshore profile consisting of fine sand. There are no runnels, rips, circulation cells, etc.; however, beach cusps of varying dimensions were frequently observed on the beach. These characteristics have some resemblance to those described by Wright et al. (1979) for reflective beaches. It should be noted that the Australian beaches described by Wright et al. are pocket beaches, while the Aruba beaches occur along an open coast. Nevertheless, the overall characteristics are quite similar.

According to Guza and Inman (1975) strong reflection of incident waves may occur if the reflectivity parameter $\epsilon<2.0-2.5$. The reflectivity parameter is defined as:

$\epsilon=a_{\mathrm{i}} \omega^{2} / g \tan ^{2} \beta$

in which $a_{\mathrm{i}}=$ incident wave amplitude near the breakpoint, $\omega=2 \pi / T$, where $T=$ wave period, $g=$ acceleration of gravity and $\beta=$ beach slope.

Under the normal conditions along the western part of the Aruban coast $\left(a_{\mathrm{i}}=0.5-1.0 \mathrm{~m}, \beta=8-15^{\circ}, T=5-8 \mathrm{~s}\right), \epsilon$ has values below 2.5 , and the beaches may be considered reflective. However, during a swell event the beach gradient becomes much flatter. As $\tan \beta$ decreases and $a_{1}$ increases $\epsilon$ will be above 2.5 despite the fact that $T$ increases and consequently $\omega$ decreases somewhat. Then a dissipative type of beach may occur. It is characterized by the presence of bars, rip cells, etc. (Wright et al., 1979).

Thus the swell event may be considered as an erosional dissipative interval in the normal accretionary, reflective beach conditions although small erosional fluctuations may be present. This interval is of a short duration (a few days) and although sand movement is extensive, a complete adaptation of the beach characteristics to the dissipative condition is hardly to be expected in such a short time. Apparently, during this dissipative interval an initial swash bar is formed. This is postulated from the fact that unit 1 is covered

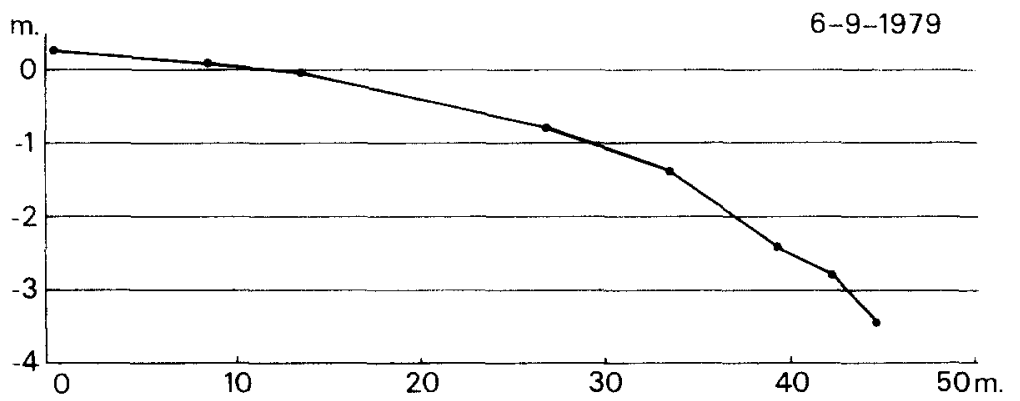

Fig.11. Example of beach profile, taken from Eagle Beach near section A. 
by the rocks and asphalt, dumped during the erosion of the beach. Thus the swash bar was already present in the swash zone, when the upper part of the beach was still eroding. The conditions during the swell event are comparable to a very rapid transition from beach stage 1-2 and reverse to 1 as described by Short (1979) and a sequence of beach profile types put forward by Sonu and Van Beek (1971) and Sonu (1973).

The continuous erosion of the upper beach during the dissipative interval resulted in a landward migration of the swash zone and hence the swash bar. This was accomplished by erosion of the seaward flank of the bar and deposition at the leeward side where a slight depression exists. In the depression at the leeward side of the bar the suspension outfall of the coarse material, produced the low-angle sigmoidal foresets and bottom sets of unit 1a, as described by Thompson (1937), Psuty (1967) and Panin (1967). In some instances, perhaps during low water the orbital velocities over the bar decreased somewhat. Then the steeper dipping tangential foresets of unit $1 \mathrm{~b}$ may be deposited. This is analogous to many observations on ridge and runnel beaches where steep slip faces of the bar are encountered during rather low orbital motion when water sweeps over the bar under limited water depth (Wunderlich, 1972; Owens and Frobel, 1977). Finally, an equilibrium developed between the flattened beach profile and the swash and backwash produced by interacting swell and wind waves, thus stopping migration of the bar.

Then the period of the gradual decrease of the swell waves started. This had a direct effect on the intensity of the swash and backwash. The mean wave run-up decreased. Still, occasional high swash ran far up the more or less dry beach but the backwash was reduced due to percolation. As a result, much material moved upslope and remained in the upper part of the profile, especially in the depression landward of the swash bar. In this way unit 2 was formed which has a similar nearly horizontal, parallel, slightly outwedging stratification as described by Thompson (1937), Panin (1967), Psuty (1967) and Hine (1979), although the laminae are remarkably thick. This suggests a high deposition rate.

As the swell waves were further reduced the relative importance of the wind waves increased. Low, wind-wave-generated swash did not overtop the swash bar anymore and a seaward outbuilding occurred on the sea facing slope of the bar. However, high (wind and swell wave) swash occasionally still swept over the bar, but on the landward side there was a very flat beach. As a result of percolation the backwash was very ineffective and almost all material moved forward by the swash, remained in the uprush zone producing an almost horizontal lamination and a heightening of the upper beach (units 3, 4).

Further decrease of the swell waves resulted in a gradual transition toward the normal steeper reflective wind-wave profiles and a seaward outbuilding of the beach (units 5-11). However, during this outbuilding, rather important erosional events took place as evidenced by truncated lamination. Over the erosive lower boundaries of the units much coarser material is 
found than is in the flatter upper parts of the units. The greater coarseness may be attributed to stronger wave action (Thompson, 1937; Hine, 1979). Apparently, increased wave energy results in erosion, steepening and selection of coarser grains in the swash zone. Waning wave energy produces accretion, less steep profiles and deposition of finer material in upward pointing wedge-shaped laminae. Such type of lamination was also reported by Thompson (1937) and Van den Berg (1977) although a conclusive explanation is still lacking.

\section{DEFORMATION STRUCTURES}

Three types of deformation structures were observed in the section: Type 1 in unit $1 \mathrm{e}$ and the lower part of unit 2; type 2 in unit 3,4 and 6, landward of the swash bar; and type 3 in several places in the seaward dipping parts of units 5-11 (Figs.8, 9, and 10).

The deformations of type 1 in unit $1 \mathrm{e}$ and lower part of unit 2 are typically encountered in the trough of the swash bar and in the last (upper) deposited sediments in this trough (Fig.9). Water escape structures and convolutions (Lowe, 1975; Reineck and Singh, 1980) were observed at several places. At other places the lamination was completely absent indicating post-depositional rearrangement of the fabric. Noteworthy are the dimensions of the undulations in the trough which have amplitudes of some decimeters. These deformation structures seem to point to conditions of "momentary failure" due to flow, induced within the porous bed (Madsen, 1974). As indicated by Madsen (1974) and by Sleath (1970), a horizontal pressure gradient may be initiated of sufficient magnitude under breaking waves to create a momentary bed failure. Structural indications of this failure are generally observed in the trough of the swash bar and not at the crest. This may indicate, that wave induced liquefaction, as described by Dalrymple $(1979,1980)$, was not the generating process of the deformation, because this type of liquefaction works out preferentially in the crestal zone of major bedforms. The position of the deformation all over the trough seems to indicate that not only horizontal but also vertical pressure gradients play an important role.

The deformations of type 2 in units 5 and 6 (Figs. 8 and 9) consist of water escape structures (pillars), convolutions, concavities, and structureless sand patches. At some places the stratification is completely disturbed. No cavernous sand is observed in the deformed layers. This excludes the formation of the convolution as a result of entrapped air as described by De Boer (1979). Furthermore, there is almost never a kind of stratification visible in the lows between the updomed parts of the convolute layers, a feature considered representative by De Boer for an air-trapped origin of the convolutions. The deformed layers much more resemble the water escape structures (dish structures, pillars) as described by Lowe (1975, figs.4 and 5). These structures are attributed to liquified behaviour of the sediment. According to Lowe, after resedimentation liquified sands may show: (1) undeformed 
primary structures; (2) deformed primary structures; (3) nearly complete homogenization; and (4) water escape structures (pillar and dish structures). The deformed sediments of units 5 and 6 do show these features. Loose packing may be expected in these swash-produced layers in this part of the units 4 and 5 . The great extension of these deformed layers and the rather sharp lower and upper boundary excludes a local origin. Generating conditions appear to have been operative over the whole top part of the upper beach. After the liquefaction the normal parallel beach lamination is restored. The reason for this alternation of liquified and non-liquified sedimentation is not clear.

The third type of deformation structure (Figs. 8 and 9) is especially visible at some places in units $7-11$. It consists of small concavities filled in with concave-upward stratified laminae. This structure shows a resemblance of hoofprints or footprints (Van der Lingen and Andrews, 1969; Lewis and Titheridge, 1978), made by horses or human beings, walking on an almost water-saturated beach or moist dune sands. This type 3 deformation structure also resembles those shown by Lindström (1979, fig.4).

\section{CONCLUSIONS}

(1) Under normal trade wind-wave conditions the calcareous-sandy microtidal beach along the west point of Aruba has a reflective character with steep beach profiles and no bars. The beach is mostly accretionary, although with small erosional fluctuations.

(2) Occasional swell events produce strong erosion and flatter beach profiles of a dissipative nature. During this condition a swash bar may be formed moving shoreward and welding to the upper beach, showing a succession of steeper and flatter landward-dipping tangential and sigmoidal sets.

(3) The gradual transition from dissipative to the normal reflective conditions creates rapid deposition in the upper part of the swash zone with substantial sub-horizontal parallel-laminated sets. In the lower part of the swash zone the beach recovery occurs by a succession of several units having a steep erosive lower boundary over which is deposited coarse material. Upward the material becomes finer and is incorporated in upward-pointing wedge-shaped sets, resulting in a gradual and slight decrease in the steepness of the beach profile.

(4) As to the preservation potential in a regressive sequence we may anticipate deposits resembling units $3-11$ in the lower part overlain by deposits related to the swell wave events. Such events, although of rare occurrence, may dominate the sedimentary sequence.

(5) Three types of deformation structures could be observed in the beach section.

\section{ACKNOWLEDGEMENTS}

This study was a part of a larger investigation requested by the Government of the Island of Aruba. We gratefully acknowledge the approval 
by this Government to publish these results. Furthermore, we benefitted much from the kind and effective cooperation of the Public Service Department (D.O.W.). Our special gratitude goes to Mr. Camminga of D.O.W. We further acknowledge the Royal Dutch Meteorological Institute for their computation of the wave fields of Hurricane David.

\section{REFERENCES}

Clifton, H.E., Hunter, R.E. and Phillips, R.L., 1971. Depositional structures and processes in the non-barred high-energy nearshore. J. Sediment. Petrol., 41: 651-670.

Dalrymple, R.W., 1979. Wave-induced liquefaction: a modern example from the Bay of Fundy. Sedimentology, 26: 835-844.

Dalrymple, R.W, 1980. Wave-induced liquefaction: an addendum. Sedimentology, 27, p. 461.

Davidson-Arnott, R.G.D. and Greenwood, B., 1976. Facies relationships on a barred coast, Kouchibouguac Bay, New Brunswick, Canada. In: R.A. Davis and R.L. Ethington (Editors), Beach and Nearshore Sedimentation. Soc. Econ. Paleontol. Mineral., Spec. Publ., 24: 140-168.

Davis, R.A, and Fox, W.T., 1972. Coastal processes and nearshore sand bars. J. Sediment. Petrol., 42: 401-412.

Davis, R.A., Fox, W.T., Hayes, M.O. and Boothroyd, J.C., 1972. Comparison of ridge and runnel systems in tidal and non-tidal environments. J. Sediment. Petrol., 42: $413-421$.

De Boer, P.L., 1979. Convolute lamination in modern sands of the estuary of the Oosterschelde, the Netherlands, formed as a result of entrapped air. Sedimentology, 26: $283-294$.

Fraser, G.S. and Hester, N.C., 1977. Sediments and sedimentary structures of a beachridge complex, southwest shore of Lake Michigan. J. Sediment. Petrol., 47: 11871200.

Greenwood, B. and Davidson-Arnott, R.G.D., 1979. Sedimentation and equilibrium in wave formed bars: a review and case study. Can. J. Earth Sci., 16: 312-332.

Guza, R.T. and Inman, D.L., 1975. Edge waves and beach cusps. J. Geophys. Res., 80 (21): 2997-3012.

Hayes, M.O., 1967. Hurricanes as geological agents, south Texas coast. Bull. Am. Assoc. Pet. Geol., 51: 937-956.

Hayes, M.O. and Boothroyd, J.C., 1969. Storms as modifying agents in the coastal environment. In: M.O. Hayes (Editor), Coastal Environments, N.E. Massachusetts and New Hampshire. Coastal Res. Group, Contrib. 1: 245-265.

Hine, A.C., 1979. Mechanisms of berm development and resulting beach growth along a barrier spit complex. Sedimentology, 26: 333-351.

Hopley, D., 1974. Coastal changes produced by cyclone Althea in Queensland, December 1971. Aust. Geogr., 12: 446-456.

Howard, A.D., 1939. Hurricane modification of the offshore bar of Long Island, New York. Geogr. Rev., 29: 400-415.

Hunter, R.E., Clifton, H.E. and Phillips, R.L., 1979. Depositional processes, sedimentary structures and predicted vertical sequences in barred nearshore systems, southern Oregon Coast. J. Sediment. Petrol., 49: 711-726.

King, C.A.M. and Williams, W.W., 1949. The formation and movement of sand bars by wave action. Geogr. J., 112: 70-85.

Kumar, N. and Sanders, J.E., 1976. Characteristics of shoreface storm deposits: modern and ancient examples. J. Sediment. Petrol., 46: 145-162.

Lewis, D.W. and Titheridge, D.G., 1978. Small scale sedimentary structures resulting from foot impressions in dune sands. J. Sediment. Petrol., 48: 835-838.

Lindström, M., 1979. Storm surge turbation. Sedimentology, 26: 115-124. 
Lowe, D.R., 1975. Water escape structures in coarse grained sediments. Sedimentology, 22: $157-204$.

Madsen, O.S., 1974. Stability of a sand bed under breaking waves. Proc. 13th. Conf. Coastal Engineering, 2: 776-794.

McKee, E.D., 1959. Storm sediments on a Pacific atoll. J. Sediment. Petrol., 29: $354-364$.

Owens, E.H. and Frobel, D.H., 1977. Ridge and runnel systems in the Magdalen Islands Quebec. J. Sediment. Petrol., 47: 191-198.

Panin, N., 1967. Structure de dépôts de plage sur la côte de la mer noire. Mar. Geol., 5: 207-219.

Psuty, N.P., 1967. The geomorphology of beach ridges in Tabasco, Mexico. Louisiana State Univ. Studies, Coastal Studies Ser., 18, $51 \mathrm{pp}$.

Reineck, H.E., 1963. Sedimentgefüge im Bereich der südlichen Nordsee. Abh. Senckenbergiana Naturforsch. Ges., 505, 138 pp.

Reineck, H.E. and Singh, I.B., 1980. Depositional Sedimentary Environments. Springer, Berlin, $549 \mathrm{pp}$.

Short, A.D., 1979. Three dimensional beach-stage model. J. Geol., 87: 553-571.

Sleath, J.F.A., 1970. Wave-induced pressures in beds of sand. J. Hydraul. Div. ASCE, 96: $367-378$.

Sonu, C.J., 1973. Three dimensional beach changes. J. Geol., 81: 42-64.

Sonu, C.J. and Van Beek, J.L., 1971. Systematic beach changes on the outer banks, North Carolina. J. Geol., 79(4): 416-425.

Stoddart, D.R., 1971. Coral reefs and Islands and Catastrophic Storms. In: J.A. Steers (Editor), Applied Coastal Geomorphology. MacMillan, London, pp. 155-197.

Thompson, W.O., 1937. Original structures of beaches, bars and dunes. Geol. Soc. Am. Bull., 48: 723-752.

Van den Berg, J.H., 1977. Morphodynamic development and preservation of physical sedimentary structures in two prograding recent ridge and runnel beaches along the Dutch coast. Geol. Mijnbouw, 56(3): 185-202.

Van der Lingen, G.J. and Andrews, P.B., 1969. Hoof-print structures in beach sand. J. Sediment. Petrol., 39: 350-357.

Wilson, W.S., 1968. On the origin of certain breakers off the Island off Aruba. Techn. Rep. Chesapeake Bay Inst. No. 43, 27 pp.

Wilson, W.S., 1969. Field measurements of swell off the Island Aruba. Techn. Rep. Chesapeake Bay Inst. No. 56, 64 pp.

Wilson, W.S., Wilson, D.G. and Michael, J.A., 1973. Analysis of swell near the Island of Aruba. J. Geophys. Res., 78(33): 7834-7844.

Wright, L.D., Chappell, J., Thorn, B.G., Bradshaw, M.P. and Cowell, P., 1979. Morphodynamics of reflective and dissipative beach and inshore systems: south-eastern Australia. Mar. Geol., 32: 105-140.

Wunderlich, F., 1972. Beach dynamics and beach development. Senckenbergiana Marit., $4: 47-79$. 